\title{
Understanding Self-Regulated Learning within an EFL Online Formative Assessment Module
}

\author{
Li Liang, Manzhen Yang* \\ School of English and Education, Guangdong University of Foreign Studies, Guangzhou, China \\ Email:11cfy2004@sina.com, *357897917@qq.com
}

How to cite this paper: Liang, L. and Yang, M.Z. (2017) Understanding Self-Regulated Learning within an EFL Online Formative Assessment Module. Open Journal of Social Sciences, 5, 312-320. https://doi.org/10.4236/jss.2017.58026

Received: July 18, 2017

Accepted: August 27, 2017

Published: August 30, 2017

Copyright @ 2017 by authors and Scientific Research Publishing Inc. This work is licensed under the Creative Commons Attribution International License (CC BY 4.0).

http://creativecommons.org/licenses/by/4.0/ (c) (i) Open Access

\begin{abstract}
Assisted with innovative internet and computer techniques, we have launched a new game-based online formative assessment reform in GDUFS in recent years. Self-regulated learning (SRL) is one of the central parts of online formative assessment and well-worth an in-depth study. But it is noted that some essential issues of formative assessment remain rarely touched yet, such as the relations among the four variables of SRL motivational strategies in the game-based blended formative assessment module. Given the above question mentioned, this paper reports a case study of SRL in an online blended formative assessment module in the context of non-English-major college English learning. The intent of the present research is to exemplify how SRL, an active area in educational psychology, can help to illustrate and understand the mechanism and correlations of the variables of SRL motivational strategies in the online formative assessment environment.
\end{abstract}

\section{Keywords}

Self-Regulated Learning, Online Formative Assessment, College Education

\section{Introduction}

Emerging since 1980s, self-regulated learning (SRL) and formative assessment have been relatively new and heated topics in the fields of learning strategy and assessment (Li, 2012) [1]. Educational testing should not merely be the assessment of learning but the assessment for learning and formative assessment is acknowledged to possess huge potential in promoting an assessment for learning. Generally speaking, in a formative assessment environment, students are self-regulated learners if they are motivationally, meta-cognitively and behaviorally active participants in their own learning process, instead of relying on 
teachers or other resources (Zimmerman, 2008) [2]. From this definition, it is argued that SRL is one of the central parts of formative assessment and well-worth an in-depth study. But Li (2012) [1] observes that some essential issues of formative assessment remain rarely touched yet, such as the relations among the four variables of SRL motivational strategies in the game-based blended formative assessment module.

Given the above question mentioned, this paper reports a case study of SRL within a game-based online blended formative assessment module (educational online game of credit coins) in the context of non-English-major college English instruction in GDUFS. Assisted with innovative internet and computer techniques, we have launched a new game-based online formative assessment reform in GDUFS in recent years. But we are still striving for some cogent empirical evidence to show that all this investment in the digital formative assessment has led to improved educational outcomes and more equal opportunities. The major research question is: what are the relations among the four variables of SRL motivational strategies in this game-based blended formative assessment module? The intent of the present research is to exemplify how SRL, an active area in educational psychology, can help to illustrate and understand the mechanism and process of SRL in the online formative assessment environment.

\section{Literature Review}

\subsection{Game-Based Blended Formative Assessment Platform}

In recent years game-based online learning has become a hotly discussed issue. Yang (2012) [3] explored the influence of a web-based educational game on students' problem-solving skills and learning achievement and found that the web-based games helped to improve students' problems-solving skills though there was no significant improvement in the students' academic achievement. Abundant studies have investigated the technology-enhanced educational games for various specific courses such as software engineering (Cagiltay, 2007) [4], mathematics (Lowrie \& Jorgensen, 2011) [5], and computer science (Papastergiou, 2009) [6]. Garris \& Driskell (2002) [7] found that games in learning can effectively stimulate the participants' intrinsic motivation. Researchers discovered that games can help to improve learners' academic achievement, motivation for learning and active participation in classroom activities, so online game-based learning can be integrated into the traditional classroom to promote students' motivation and active attendance (Carnevale, 2005) [8]. Wang (2008) [9] investigated the web-based quiz-game-like formative assessment and verified that game-based formative assessment could enhance learners' motivation to use online assessments. However, among the researches so far, the interaction of the mechanisms of game-based online formative assessment module has remained an unknown and challenging issue. Given the above mentioned, our research team has carried out a game-based blended formative assessment educational reform in an effort to integrate the ideology of games with formative assessment 
in-class and online blended-teaching for over two years. An online platform (http://evaluate.fifedu.com, as seen in Figure 1) has been designed and developed to meet the requirements of the game-based teaching and learning for different courses within the formative assessment module.

\subsection{Self-Regulated Learning}

Self-regulation includes a series of sophisticated super-ordinate functions such as cognition, metacognition, problem-solving and motivation. Self-regulated learning (SRL), a key section in formative assessment module, is a sub-construct under the concept of self-regulation (Boekaerts \& Corno, 2005) [10]. Since SRL is basically a process of applying cognitive and meta-cognitive strategies in learning, this study adopts the theoretical framework of Bandura's social cognitive theory (Bandura, 1986; 2001) [11] [12]. According to this theory, the environment affects people's cognition and behavior, while people are viewed as both products and producers of the environment in which their cognitive and behavioral funtions are determined. The views about SRL are essentially focused on the concept of agency. Agency determines the environment and is determined by the environment. Agency posesses four features: intentionality, forethought, self-reactiveness, and self-reflectivenes. Thus, human agency refers to an emergent ability of a person to make choices and to act on these choices through interaction between mind and sociocultural contexts (Bandura, 1986) [11]. In the case of SRL, the learners participate in study activities with purpose and their learning behaviors are directed by their anticipated goals, outcomes and plans. The learners are not only the agents of study but also self-examiners

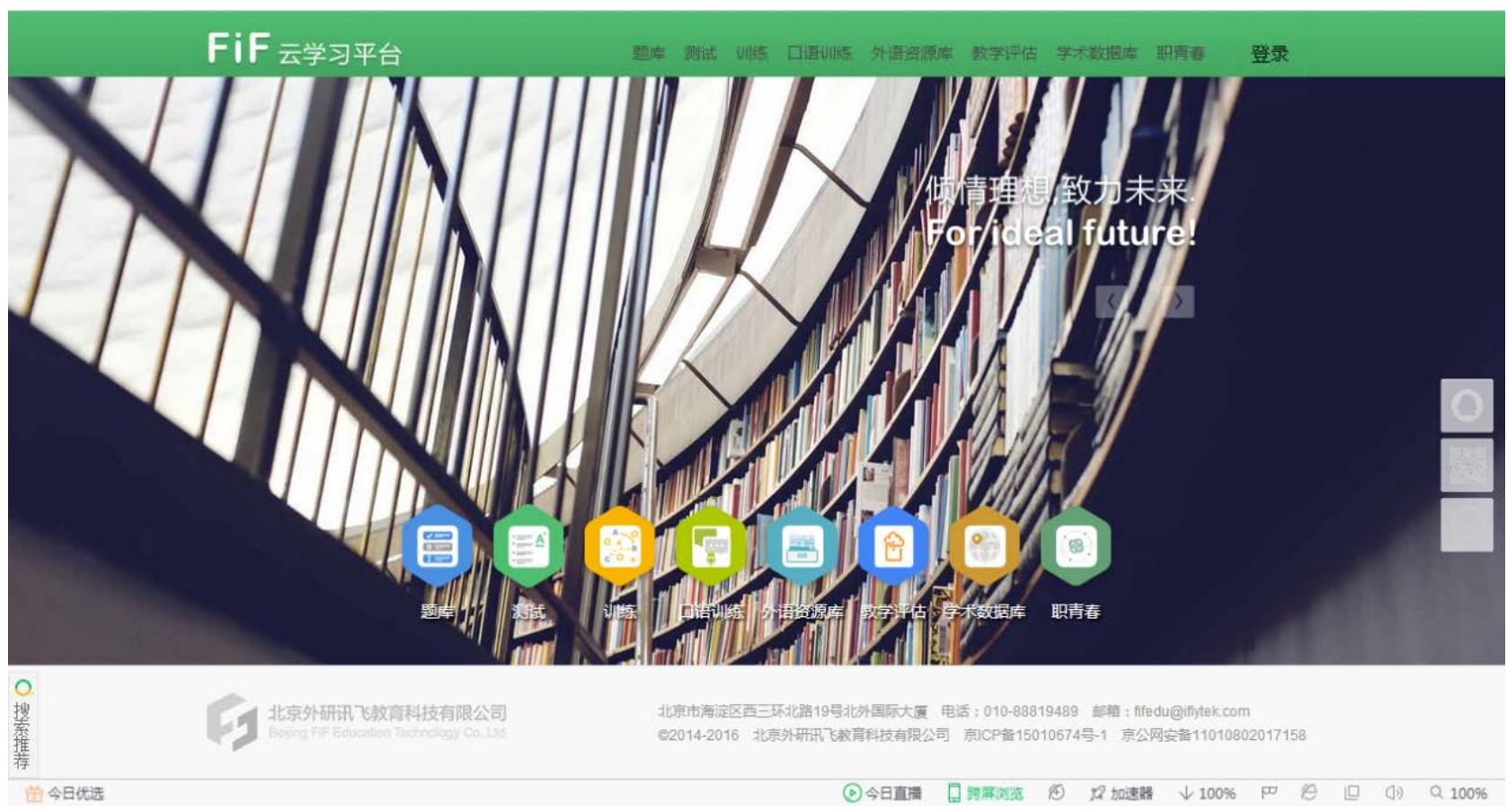

Figure 1. FIF formative assessment online platform. 
of their study. Thus, the concept of agency indicates that we need to investigate the two key elements of SRL-motivation and metacognition.

\subsection{Motivation \& Metacognition}

Metacognition refers to the study of people's knowledge of their cognitive and memory processes, and how they apply the metacognitive knowledge in their information processing and behavior (Koriat, 2007) [13]. Schunk et al. (2008: 4) [14] define motivation as "the process whereby goal-directed activity is intigated and sustained". In this sense, learners' motivation, as an inner psyche process, can be inferred from its products-specific observable behavior such as the choice of learning tasks, how to deal with problems and the length of time allocated for study. Motivation can be divided into intrinsic and extrinsic motivation. Learners have been assumed to be the masters (i.e. agents) of the technology-assisted learning and the digital technologies can be used not just as cognitive tools but also as metacognitive tools (Chen, et al., 2008) [15]. The impact of motivation on learning mainly lies in behavioral and cognitive engagement (Linnenbrink \& Pintrich, 2003) [16]. Therefore, our investigation of self-regulated learners' motivation includes not only a four-subscale survey questionnaire, but also the major aspects of learning including learning outcomes and length of time for study. Besides that, self-efficacy is also a significant motivational construct of human agency as it is found that learners with high self-efficacy beliefs are more willing to spare more effort in overcoming difficulties and persist at learning tasks. According to social cognitive theory, self-efficacy refers to a belief about one's ability to accomplish a learning task (Bandura, 1986) [11]. Gao (2010) [17] examined a disabled learners' autonomous language learning and revealed the learner's agency played an non-ignorable role in shaping her motivational discourses, beliefs and strategic efforts. Li \& Liu (2015) [18] reviewed the researches on Chinese EFL learners' motivation from 2004 to 2013 and noted the problem of limited perspectives and few longitudinal empirical researches. Besides that, little is known about to what extent the students' self-efficacy, intrinsic and extrinsic motivation can predict their strategic regulation of learning in the game-based blended formative assessment module, although the students' strategic regulation of learning plays a significant role in affecting their specific regulative behavior in learning such as dealing with the problems and the arrangement of time for study.

In consideration of the above mentioned, we designed a set of credit-coin game rules for the in-class and online blended formative assessment environment. The teachers assess the students' learning performance and efforts in terms of credit coins recorded in the online platform. For instance, the student hand in homework as required will be awarded ten credit coins in his or her credit coin account in the online platform and the A level homework will get an extra award of 15 coins. Therefore, the amount of credit coins indicates the levels of his or her learning efforts and outcomes (Figure 2). 


\subsection{A Proposed Analytical SRL Model as Metacognitive and Motivational Tools}

Given the above researches on SRL, we propose an analytical SRL model (Figure 3) to clarify the research focus so as to provide useful contributions for the improvement of the game-based blended formative assessment module. This study focuses on the mutual interactions among the three factors: the students' SRL motivational strategies, the students' learning behavior and the game-based blended formative assessment module. This model comprises three dimensions of implications: 1) SRL is a learning process in which the students exercise their cognitive, metacognitive and motivational factors of human agency; 2) the students' level of motivational strategies elicits the corresponding learning behaviors; 3 ) the relations and interaction among the three factors need to be investigated if we aim to improve the game-based blended formative assessment module.

\section{Method}

\subsection{Participants}

The participants ( $\mathrm{N}=358$ ) were first-year non-English-major college students in a Cantonese university in the academic year of 2014-2015, the majors of whom include accountant, finance and business management. There were 107 male students and 257 females, who came from urban and rural areas throughout China. The survey statistics indicated that there was no significant differences in
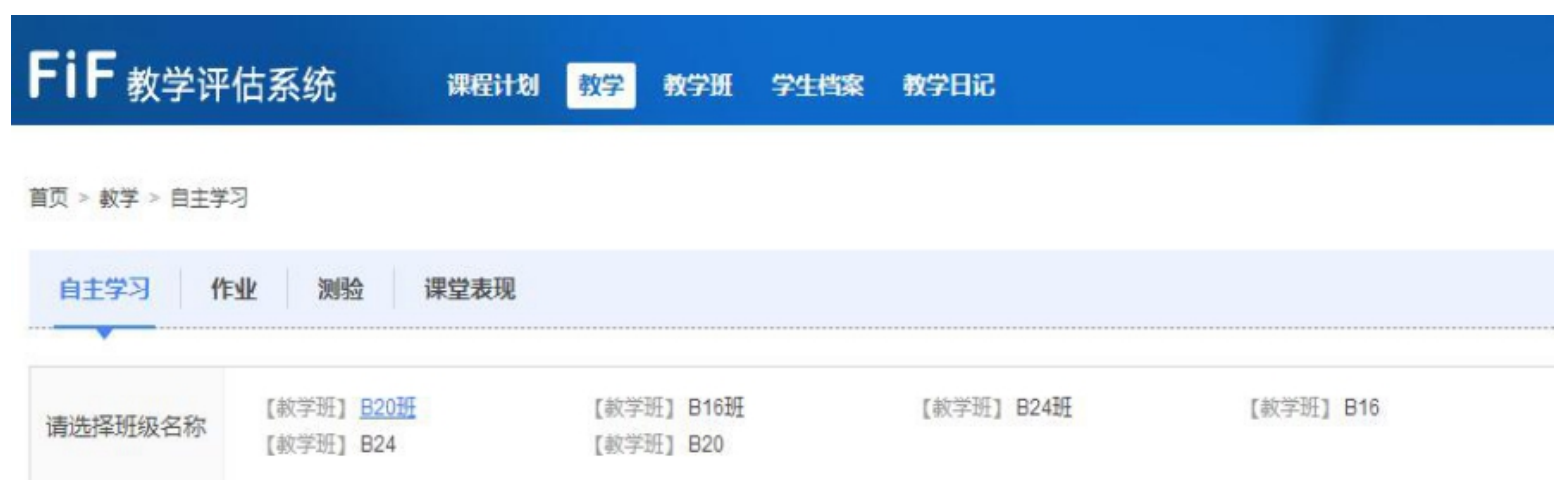

$\begin{array}{lcccc}\text { 学生姓名 } & \text { 已学总单元数 } & \text { 各单元学习总时长 } & \text { 获得奖励总数 } & \text { 操作 } \\ \text { 黄思华 } & 11 & \text { 248分钟 } & 106 & \text { 详倩 } \\ \text { 关芷睛 } & 11 & \text { 185分钟 } & 112 & \text { 详情 } \\ \text { 区嘉文 } & 10 & \text { 131分钟 } & 112 & \text { 详情 } \\ \text { 黄韵 } & 8 & \text { 227分钟 } & 111 & \text { 详情 } \\ \text { 梁裕俊 } & 10 & \text { 301分钟 } & 119 & \text { 详情 } \\ \text { 范嘉恩 } & 17 & \text { 246分钟 } & 105 & \text { 详情 }\end{array}$

Figure 2. Illustration of credit coin accounts on the FiF platform. 
Game-based blended formative assessment module

SRL motivational strategies

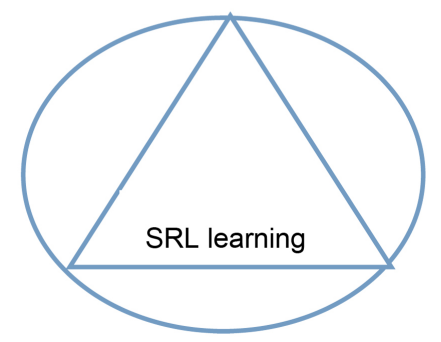

SRL learning outcomes

Figure 3. An analytic SRL model of game-based blended learning.

the SRL motivational and metacognitive variables between the genders ( $\mathrm{p}>$ 0.05). Those who took part in the game-based blended formative assessment module for one term accounted for 152 (three classes of students), while the number of those who participate in this educational reform module for two consecutive terms were 206 (five classes of students).

\subsection{Procedure}

Based on the class observation and students' feedback, an extensive online survey from sojump.com was designed and carried out among the eight classes of freshman students participated in the game-based blended formative assessment module in the academic year of 2014-2015. The survey was piloted on a sample of ten students and two teaching-research staffs. Then the survey was fine-tuned by deleting or modifying some items and wording. Three out of the eight classes of students joined this educational reform module for one term and the other five classes participated in this reform module for two terms. The survey was administered anonymously online twice separately at the end of each term of this academic year (i.e., December 2014 and June 2015).

\subsection{Data Collection}

The quantitative measurement in the present study can be grouped into three categories: the students' self-report surveys, weekly length of time online on average and learning outcome (number of credit coins gained in the individual account in the online platform). The number of valid questionnaires collected was three hundred and fifty-eight. First, the 5-point Likert scale survey was developed on the basis of the MSLQ (Duncan \& McKeachie, 2005 [19]; Pintrich, et al., 1993 [20]). Then the survey was administered in the classes anonymously twice. This survey measures three motivational variables (self-efficacy (SE), intrinsic motivation (IM), and extrinsic motivation (EM)) and one metacognitive awareness variable (strategic regulation of learning). There are twenty-three items in the four subscales of this survey and all items are directly defined in the context of EFL learning, transforming the widely used instrument for measuring motivated strategies for learning MSLQ questionnaire into an appropriate scale for the context of game-based EFL blended classes. The students were required 
to select an answer from the five options in the 5-point Likert scale: strongly agree, agree, neutral, disagree, and strongly disagree, which were coded as 1, 2, 3, 4, 5 respectively in the data analysis. Thus, the higher score in a subscale one reported, the lower value he or she would have in that subscale. The Chronbach's alpha value of the total questionnaire is 0.768 and the standardized alpha value is 0.772 , which indicates that the scores in the questionnaire are reliable.

The present study uses SPSS Statistics 16 to analyze the data: Pearson correlates analysis was applied to examine the correlations among the four variables.

\section{Results and Discussion}

\subsection{Correlations among the Variables}

Table 1 shows the Pearson correlations between the four variables and some positive associations among them are discovered.

Firstly, the positive correlation between the strategic regulation of learning and the two variables (self-efficacy and intrinsic motivation), and that between intrinsic motivation and self-efficacy, are moderate. Secondly, the positive correlation between strategic regulation of learning and extrinsic motivation, and that between extrinsic motivation and the two variables (self-efficacy and intrinsic motivation), are weak. Thirdly, as $r>0.70$ among these four variables, multiple regression analysis can be employed to explore to what extent the SRL motivational variables predict the metacognitive variable (strategic regulation of learning).

\subsection{SRL Variables and Formative Assessment Reform}

It is shown that there is moderate positive correlation among self-efficacy, inner motivation and strategic regulation of learning in the context of formative assessment reform. Thus, we can improve the students' self-efficacy level by promoting their inner motivation and strategic regulation of learning. The higher the students' inner motivation and strategic regulation of learning are, the higher their self-efficacy will be. This is of practical implication for the formative assessment reformers and teachers at the tertiary level.

Weak positive correlation is found among the university students' extrinsic motivation, self-efficacy and strategic regulation of learning, which means that the variation in the extrinsic motivation level usually will not cause significant

Table 1. Pearson correlations between the measured variables.

\begin{tabular}{ccccc}
\hline & 1 & 2 & 3 & 4 \\
\hline 1. self-efficacy & & & \\
2. Intrinsic motivation & $0.58^{* *}$ & & \\
3. Extrinsic motivation & $0.35^{* *}$ & $0.30^{* *}$ & \\
4. Strategic regulation of learning & $0.56^{* *}$ & $0.58^{* *}$ & $0.38^{* *}$ \\
\hline${ }^{* *} \mathrm{p}<0.01$. & &
\end{tabular}


change in these three SRL variables. Thus, the university students' inner and extrinsic motivations have different functions in stimulating and maintaining their SRL behavior. The variation in university students' innner motivation will often lead to the changes in their self-efficacy and strategic regulation of learning, while extrinsic motivation will not. In this sense, the extrinsic motivation has limited impact on SRL motivational strategies and learning outcomes at tertiary level. Therefore, for the formative assessment reformers and teachers, the key to improve learning outcome does not lie in stimulating university students' extrinsic motivation but promoting their self-efficacy, inner motivation and strategic regulation of learning. For the formative assessment reform researchers, university students' inner and extrinsic motivations should be investigated separately instead of mixing them up as one variable because these two functions differently in university students' SRL behavior.

\section{Conclusion}

This research discovers that the students in this credit coin game of learning have significantly profited their English as foreign language learning. Self-efficacy, inner and extrinsic motivations have significant impact on strategic regulation of learning. Self-efficacy is the crucial variable for the SRL outcomes and regulation. Debriefing adopted in the game-based formative assessment module is an effective way to improve the students' self-efficacy. More research should be done to explore some feasible ways to encourage autonomous self-regulated learners.

\section{Acknowledgements}

This paper was supported by a grant from Guangdong Department of Education.

\section{References}

[1] Li, Q. (2012) The Present and Future of the Formative Assessment. Foreign Language Testing and Teaching, 3, 1-8.

[2] Zimmerman, B.J. (2008) Investigating Self-Regulation and Motivation: Historical Background, Methodological Developments, and Future Prospects. American Educational Research Journal, 45, 166-183. https://doi.org/10.3102/0002831207312909

[3] Yang, Y.-T.C. (2012) Building Virtual Cities, Inspiring Intelligent Citizens: Digital Games for Developing Students' Problem Solving and Learning Motivation. Computers \&Education, 59, 365-377. https://doi.org/10.1016/j.compedu.2012.01.012

[4] Cagiltay, N.E. (2007) Teaching Software Engineering by Means of Computer-Game Development: Challenges and Opportunities. British Journal of Educational Technology, 38, 405-415. https://doi.org/10.1111/j.1467-8535.2007.00705.x

[5] Lowrie, T. and Jorgensen, R. (2011) Gender Differences in Students' Mathematics Game Playing. Computers \& Education, 57, 2244-2248.

https://doi.org/10.1016/j.compedu.2011.06.010

[6] Papastergiou, M. (2009) Digital Game-Based Learning in High School Computer Science Education: Impact on Educational Effectiveness and Student Motivation. 
Computers \& Education, 52, 1-12. https://doi.org/10.1016/j.compedu.2008.06.004

[7] Garris, R., Ahlers, R. and Driskell, J. (2002) Games, Motivation, and Learning: A Research and Practice Model. Simulation \& Gaming, 33, 441-467. https://doi.org/10.1177/1046878102238607

[8] Carnevale, D. (2005) Run a Class Like a Game Show: "Clickers" Keep Students Involved. Chronicle of Higher Education, 51, B3-B9.

[9] Wang, A.I., Elvemo, A.A. and Gamnes, V. (2014) Three Social Classroom Applications to Improve Student Attitudes. Education Research International, 1-14. https://doi.org/10.1155/2014/259128

[10] Boekaerts, M. and Corno, L. (2005) Self-Regulation in the Classroom: A Perspective on Assessment and Intervention. Applied Psychology. An International Review, 54, 199-231. https://doi.org/10.1111/j.1464-0597.2005.00205.x

[11] Bandura, A. (1986) Social Foundations of Thought and Action: A Social Cognitive Theory. Prentice-Hall, Englewood Cliffs, NJ.

[12] Bandura, A. (2001) Social-Cognitive Theory: An Agentic Perspective. Annual Review of Psychology, 52, 1-26. https://doi.org/10.1146/annurev.psych.52.1.1

[13] Koriat, A. (2007) Metacognition and Consciousness. In: Zelazo, P.D., Moscovitch, M. and Thompson, E., Eds., The Cambridge Handbook of Consciousness, Cambridge University Press, Cambridge, 289-325. https://doi.org/10.1017/CBO9780511816789.012

[14] Schunk, D.H., Pintrich, P.R. and Meece, J.L. (2008) Motivation in Education: Theory. 3rd Edition, Pearson Education Inc., London.

[15] Chen, W., Tan, N.Y.L., Looi, C.-K., Zhang, B.H. and Seow, P.S.K. (2008) Handheld Computers as Cognitive Tools: Technology-Enhanced Environmental Learning. Research \& Practice in Technology Enhanced Learning, 3, 231-252. https://doi.org/10.1142/S1793206808000513

[16] Linnenbrink, E.A. and Pintrich, P.R. (2003) The Role of Self-Efficacy Beliefs in Student Engagement and Learning in the Classroom. Reading \& Writing Quarterly, 19, 119-137. https://doi.org/10.1080/10573560308223

[17] Gao, X. (2010) Autonomous Language Learning against All Odds. System, 38, 580-590. https://doi.org/10.1016/j.system.2010.09.011

[18] Li, J. and Liu, P. (2015) A Review of Researches on China's EFL Motivation (2004-2013). Foreign Language World, 167, 34-43.

[19] Duncan, T.G. and McKeachie. W.J. (2005) The Making of the Motivated Strategies for Learning Questionnaire. Educational Psychologist, 40, 117-128. https://doi.org/10.1207/s15326985ep4002_6

[20] Pintrich, P.R., Smith, D.A., Garcia, T. and McKeachie, W.J. (1993) Reliability and Predictive Validity of the Motivated Strategies for Learning Questionnaire (MSLQ). Educational and Psychological Measurement, 53, 801-813. https://doi.org/10.1177/0013164493053003024 
Submit or recommend next manuscript to SCIRP and we will provide best service for you:

Accepting pre-submission inquiries through Email, Facebook, LinkedIn, Twitter, etc. A wide selection of journals (inclusive of 9 subjects, more than 200 journals)

Providing 24-hour high-quality service

User-friendly online submission system

Fair and swift peer-review system

Efficient typesetting and proofreading procedure

Display of the result of downloads and visits, as well as the number of cited articles Maximum dissemination of your research work

Submit your manuscript at: http://papersubmission.scirp.org/

Or contact jss@scirp.org 